Issues in the school-to-work transition of hard of hearing adolescents

\author{
Renée Punch \\ Merv Hyde \\ Peter A. Creed \\ Griffith University \\ Gold Coast \\ Australia
}




\title{
Issues in the school-to-work transition of hard of hearing adolescents
}

\begin{abstract}
Career theorists emphasize the importance of the development of career maturity in adolescents if they are to successfully negotiate the school-to-work transition. Transitions of young deaf and hard of hearing people the transition may be especially problematic. The authors examine the implications of current labor market trends for young people, in particular for those with hearing loss, and review data on employment outcomes for deaf and hard of hearing people. They discuss the environmental and attitudinal barriers that can influence the career outcomes and advancement of this population, consider the impact of hearing loss on adolescents' career maturity, and review the studies on this topic in the literature. The article focuses on the experiences of students with significant hearing loss who are educated in regular classes with the support of itinerant teachers, who communicate orally, and who may be defined as hard of hearing. Recommendations for research and practice are provided.
\end{abstract}


In most English-speaking countries, the great majority of students with significant sensorineural hearing loss attend regular schools. In Australia, an estimated 85\% of deaf and hard of hearing students now attend regular classes, with support from itinerant teachers of the deaf; most of the remainder are placed in special education units in regular schools, and attend the schools’ regular classes to varying degrees (Power \& Hyde, 2002). These proportions are higher than those in the United States and the United Kingdom, although they reflect similar trends in those countries away from special schools and towards education in general classes (Luckner \& Muir, 2001; Lynas, Lewis, \& Hopwood, 1997).

A recent Australian study found that a surprisingly high $64 \%$ of students in regular classes with itinerant teacher support had severe or profound hearing loss (Power \& Hyde, 2002). These students effectively used their amplified residual hearing and communicated orally and, based on the findings of the study, may be functionally defined as hard of hearing. Although the term hard of hearing has often been used to describe people with less than severe hearing loss, its definition is being increasingly adopted to include people with all levels of hearing loss whose communication mode is primarily oral-aural and who effectively use their residual hearing supplemented by speechreading and assistive hearing devices (Israelite, Ower, \& Goldstein, 2002; Laszlo, 1994; Warick, 1994). It is this definition of the term that we use in the present article.

While differing in their needs from deaf students who utilize a sign language, young people who are hard of hearing face difficulties not faced by their normally hearing peers. One area in which more needs to be known about hard of hearing youth's difficulties and needs is career development and the school-to-work transition, especially as one of the likely expectations of parents, teachers, and the students themselves is that the inclusion of these students will continue into vocational settings.

\section{Current Labor Market Trends and Their Implications for Young People}

In recent decades, advanced industrial countries such as the United States, the United Kingdom, and Australia have experienced massive social and economic changes, moving from industrially based to technologically based societies, their labor markets characterized by shrinking manufacturing sectors and burgeoning service sectors. These changes, along with related factors 
such as economic globalization and organizational restructuring and downsizing, have had powerful effects on labor markets. In general, advanced industrial societies demand bettereducated and more technically skilled workforces (Furlong \& Cartmel, 1997). However, there is also growth in poorly paying, low-skill work with minimal prospects, often comprising part-time and casual employment (Murphy \& Noad, 1995). Even for highly qualified workers, permanent full-time positions have been replaced in many organizations by contract positions, often short term and performance based (Hall \& Mirvis, 1996). Outsourcing of tasks means that more employees work for small and medium-sized rather than large organizations and more people are self-employed (Watts, 1997). Within organizations, teamworking, multiskilling and continually changing technologies necessitate good communications skills, flexibility, and the ability to be a continuous learner (Mirvis \& Hall, 1996; Watts, 1997). The traditional notion of career and job security is no longer a reality; for individuals to thrive in this environment, qualities such as adaptability, flexibility, and self-direction are essential (Hall \& Mirvis, 1996).

For youth, these changes have made the transition from school to work far more complex than it used to be: It has become more protracted, more fragmented, and less predictable (Furlong \& Cartmel, 1997). Full-time job opportunities have decreased dramatically for teenagers leaving school, and this group's unemployment rates have increased. In the United States, the unemployment rate in mid-2003 for people aged 16 to 19 years was 19\%, compared to only 6.2\% for the population as a whole (Bureau of Labor Statistics, 2003). Similarly, 22.5\% of 15- to 19year-olds in Australia were unemployed in the year 2000-01, compared to 6.4\% of the general population (Australian Bureau of Statistics, 2002b). The full-time jobs that do exist for workingage teenagers have increasingly tended to involve lower-paid and less skilled work (Sweet, 1998).

These major changes in the labor opportunities for teenagers have contributed to higher school retention rates and higher levels of participation in higher education. For example, in Australia the rate of retention to the final year of school rose from 52\% in 1986 to $75.4 \%$ in 2001 (Australian Bureau of Statistics, 2002a). Opportunities for access to higher education are available to many more young people than in the past; by the late 1990s, 40\% of young Australians were entering university degree or Technical and Further Education college (TAFE) associate diploma courses after leaving school, compared to 20\% in 1980 (Long, Carpenter, \& Hayden, 1999). However, school-leavers now face pressures such as increased competition for 
tertiary places and a far greater diversity and complexity of school and post-school options and pathways (McCowan \& McKenzie, 1997).

School-leavers who do not participate in higher education, vocational training, or apprenticeships are vulnerable to marginalization in the work-force, moving from school into poorly paid part-time or temporary work and finding it difficult to break out of a cycle that intersperses periods of part-time work with periods of unemployment (Sweet, 1998; Vondracek \& Porfeli, 2003). A recent study highlights this situation in Australia. Extensive data from the Longitudinal Survey of Australian Youth, which investigated the post-school experiences of two cohorts who left school in the late 1980s and mid 1990s, revealed that 32\% of the school-leavers who did not go on to obtain a tertiary qualification experienced a problematic transition period characterized by part-time work and periods of unemployment, compared to only 6\% of students who obtained a university degree or TAFE diploma. Early school-leavers are at even more risk: the rate of unemployment among those who leave school in the $10^{\text {th }}$ grade is well above that of those who complete $12^{\text {th }}$ grade. Students with disabilities experience particular difficulties in making the school-to work transition. Considerably higher rates of long-term unemployment (13\% among those with a disability compared to 7\% among peers without a disability), mainly part-time work (8\% compared to $4 \%$ ) and complete non-participation in the labor force (18\% compared to 5\%) were found in the Australian study (Lamb \& McKenzie, 2001).

Young people's transition from school to a working life, then, is an increasingly complex and uncertain experience, and, for some, an extremely difficult one possibly leading to long-term marginalization. For people with disabilities in general, and for young deaf and hard of hearing people in particular, the transition is likely to be especially problematic. This is of particular concern in the light of the difficulty deaf and hard of hearing people historically have had achieving parity of employment outcomes with normally hearing people.

\section{Employment Outcomes for Deaf and Hard of Hearing People}

It is difficult to draw conclusions about the employment achievement of deaf and hard of hearing people as this is a highly heterogeneous population. Most studies do not differentiate between people who use a sign language and those who are primarily oral-aural in their communication. However, evidence indicates that deaf and hard of hearing people have been under-represented in professional and managerial occupations, and over-represented in blue-collar occupations, especially in manufacturing (Bullis, Bull, Freeburg, \& Sendelbaugh, 1990; Hyde \& Power, 1992; 
Schildroth, Rawlings, \& Allen, 1991). Relative to their hearing peers, deaf adults have been found to be less educated, to experience more unemployment and underemployment, and to have lower incomes; deaf women have been found to be even more affected than deaf men (MacLeodGallinger, 1992).

A major study was conducted by The University of Arkansas Rehabilitation Research and Training Center for Persons who are Deaf or Hard of Hearing over a period of 15 years based on a national longitudinal survey of deaf and hard of hearing graduates of 2-year and 4-year colleges and technical institutes (El-Khiami, 1993; Schroedel \& Geyer, 2000). Approximately 70\% of these study respondents considered themselves to be deaf and 30\% stated they were hard of hearing. El-Khiami, reporting on the employment status and career experiences of the sample 5 years after the completion of their postsecondary program, described an extremely positive college-to-work transition for the respondents, with only $4 \%$ not having joined the workforce, and the remainder finding jobs immediately or within a few months after graduation. Over 29\% of graduates reported working in a professional or managerial occupation, with $46 \%$ working in the technical and clerical areas. Seven years later, Schroedel and Geyer found that the percentage of respondents working in professional, managerial, and technical occupations had increased, with a parallel decrease in the percentage of those working in clerical occupations. Many of the respondents had also become better educated in the interim, with some who had earned vocational or associate's degrees having since obtained bachelor's degrees, and some previous bachelor’s degree recipients having gone on to obtain master's degrees.

However, Schroedel and Geyer (2000) also found that 5\% of the alumni in the University of Arkansas study were unemployed and 15\% were underemployed (defined as being a worker with educational attainments that exceed the educational attainments usually required for the occupation in which the worker is employed; in this study, bachelor's degree holders working in clerical or crafts occupations were considered to be underemployed). Another finding of potential concern was that the educational, occupational, and economic attainments of hard of hearing graduates were significantly less than those of deaf graduates. More than $62 \%$ of the deaf graduates, but only $38.5 \%$ of the hard of hearing graduates, were employed in professional, managerial, and technical jobs; $36.5 \%$ of the hard of hearing respondents were employed in crafts, machine operative, and labor occupations, compared to $14 \%$ of the deaf respondents. Level of education was a related factor: Deaf graduates obtained higher levels of postsecondary education than their hard of hearing counterparts. While pointing out that the hard of hearing 
respondents in the study attended colleges providing support programs and may have differed from hard of hearing alumni of colleges without support programs, Schroedel and Geyer did not speculate on why the deaf students attained higher educational levels than the hard of hearing students.

Alumni of postsecondary educational institutions are not, of course, representative of all young people who have left school. Other studies have included broader populations and have compared postsecondary education rates and employment outcomes of deaf and hard of hearing young people with those of hearing peers. A study comparing the transition experiences of 217 deaf young adults with a similar number of hearing peers 3 to 4 years after leaving high school in the northwestern United States discovered significantly lower rates of postsecondary enrolment, employment, and pay for the deaf group than for the hearing group (Bullis, Bull, Johnson, \& Peters, 1995). Although Bullis and colleagues did not specify participants' levels of hearing loss, they did report that almost $60 \%$ the deaf group had attended residential schools for the deaf, with the remainder having attended school in mainstream settings, and that $48 \%$ of the residential group and 36\% of the mainstreamed group had additional disabilities, compared to $9 \%$ of those in the hearing group.

Another extensive study was based on a survey of high school students with hearing losses over 70dB conducted in 1987, with a follow-up in 1991, by the Centre for Assessment and Demographic Studies, Gallaudet University (Allen, 1994; Lam, 1994; Rawlings, 1994). Rawlings reported postsecondary education rates among the follow-up sample to be similar to those of hearing peers, with approximately two-thirds enrolled in or having attended postsecondary educational programs. In investigating the $34 \%$ of the sample who did not attend postsecondary education, Lam found only $54 \%$ in full-time or part-time employment. Of the employed, $72 \%$ were in blue-collar jobs such as clerk/typist, kitchen worker, cleaner, and assembler. Minimal wages, little hope of promotion, and part-time work were common factors among these workers. It is pertinent, however, that $47 \%$ of the non-college bound sample had disabilities additional to their deafness, compared with $20 \%$ of the group who attended postsecondary educational programs.

A Swedish study used semistructured interviews to compare decision processes and transition outcomes of two groups of hard of hearing young adults 5 years after completing secondary schooling: those who had attended university, labeled in the study the University Group, and those who had not, labeled the Labor Market Group (Danermark, Antonson, \& 
Lundstrom, 2001). The Labor Market Group had a somewhat lower academic achievement level than the University Group, but slightly better hearing status. All participants attended the National School for the Hard of Hearing and used oral-aural communication. Students in this study who had chosen narrow, vocationally oriented courses for their postcompulsory secondary school years were, 5 years later, disappointed with their occupational experiences, which included unskilled, poorly paying jobs and periods of unemployment

Studies of the employment outcomes of deaf and hard of hearing Australians are scarce. Reflecting the North American findings, a study of South Australian deaf adults aged 18 to 50 years found higher levels of unemployment and underemployment among its sample, particularly among the women, relative to South Australian and national averages for all employed persons (Winn, 1997). An early survey exploring the employment status and educational needs of young people with hearing loss in the state of Queensland found an extremely high level of unemployment (37\%), with the majority of those employed working in areas such as laboring or clerical activities (Hyde, 1988). The situation for deaf and hard of hearing youth has changed since this study, with higher school retention rates and improved conditions for students with hearing loss, including the legal requirement that educational institutions provide necessary services and facilities to students with disabilities (McLean, Osborne, McAuliffe, Housden, \& Revens, 1999). Although the number of deaf and hard of hearing students enrolled in postsecondary education has increased in both Australia and the United States, rates of participation of this population still do not match those of the hearing population (Bullis et al., 1995). This finding underscores the importance of planning for college when planning the transition of deaf and hard of hearing students (Bonds, 2003).

In summary, it appears that the deaf and hard of hearing population, despite a normal distribution of intelligence and aptitudes, continues to be more at risk of problematic transition, less postsecondary education and higher rates of unemployment and underemployment than the hearing population. Contributing to this situation are factors such as the deaf and hard of hearing population's literacy and educational achievement levels, as well as environmental and attitudinal barriers. 


\section{Factors Contributing to Unsatisfactory Career Outcomes Literacy and Educational Achievement Levels}

Lower levels of English literacy and numeracy relative to their hearing peers have constituted a serious obstacle to postsecondary education, initial employment, and workforce advancement for deaf and hard of hearing people (Bat-Chava et al., 1999). The educational achievement and literacy levels of deaf and hard of hearing children have generally been reported as being considerably below those of their hearing peers. Many studies measuring reading comprehension levels report average reading ages many years below chronological age (e.g., Allen, 1986; Conrad, 1979; Power, 1998; Welsh, 1993).

Nevertheless, several experts now suggest that many children with severe and profound hearing loss achieve higher functional literacy levels than has previously been thought (Moores, 2001; Toscano, McKee, \& Lepoutre, 2002). Standardized reading tests often underestimate students' comprehension, which is shown to be greater when assessment techniques emphasizing context and a search for meaning are employed (Moores, 2001; Power, 1998). Studies have confirmed that high literacy levels do exist among deaf and hard of hearing students. Studies of students with severe and profound hearing loss in mainstream oral programs by Geers and Moog (1989) in North America and Lewis (1996) in England found considerably higher levels than previously reported for deaf and hard of hearing students, and reveal the potential of students with severe and profound hearing losses to achieve age-appropriate literacy levels. So, although low literacy and educational achievement levels continue to contribute to the transition difficulties of many deaf and hard of hearing school-leavers, these conditions may now pose less of a barrier to career achievement for this population than they did in the past.

\section{Attitudinal and Environmental Barriers}

Difficulties in gaining appropriate employment and advancement in employment are experienced by people with hearing loss even when their literacy and educational levels are adequate or more than adequate. Environmental and attitudinal barriers in the workplace contribute to these difficulties, as they do for most people with disabilities. As vocational rehabilitation experts Edna Szymanski and David Hershenson (1998, p. 332) assert, “The limitations of disabilities are not inherent within individuals, but rather in individuals' interactions with their environments”. Environmental barriers constitute physical or structural impediments, and as such have the potential to cause an impairment to become a disability, in the terms of the World Health 
Organization's (1980) definitions. For people with hearing loss, such barriers include the requirement that workers use telephones, background noise in the workplace, and auditory rather than visual alerting signals (DeCaro, Mudgett-DeCaro, \& Dowaliby, 2001; Laroche, Garcia, \& Barrette, 2000; Winn, 1997). Jobs in the growing service sector usually require considerable amounts of verbal interaction with customers or clients; this interaction is certainly possible but can be problematic for deaf and hard of hearing people (Schildroth et al., 1991). The most difficult workplace situations reported by deaf and hard of hearing people, however, involve group situations such as departmental and staff meetings, in-service training sessions, and workrelated social functions - all situations that are important to career maintenance and advancement (Laroche, Garcia, \& Barrette, 2000; Scherich, 1996; Scherich \& Mowry, 1997).

Environmental barriers can be reduced by the altering of workplace conditions through the provision of accommodations. Enacted in 1990, the Americans With Disabilities Act requires employers of 15 or more persons to make reasonable accommodations so that qualified workers with disabilities have equal employment opportunity. In Australia, the Disability Discrimination Act (1992) requires employers to provide services or facilities to enable a suitably qualified person with a disability to perform the "inherent requirements of the particular employment" as long as such provision would not impose an "unjustifiable hardship” on the employer (section 15, 4, b).

However, many studies have shown that necessary, reasonable accommodations are difficult to obtain or not forthcoming for many workers with disabilities in general (Harlan \& Robert, 1998) and hearing loss in particular (Geyer \& Schroedel, 1999; Scherich, 1996; Scherich \& Mowry, 1997; Stika, 1997). In their studies of workers with hearing loss, Scherich and Mowry and Scherich found that the most commonly provided accommodations were assistive devices such as amplified telephones and text telephones. The use of support personnel tended to be on an informal rather than a formal basis; for example, a co-worker might agree to make telephone calls for the worker with hearing loss. A significant proportion of respondents (62\%) stated that their present accommodations did not meet their needs, and 31\% reported that they had been denied a requested accommodation. The studies found that employers recognized the needs of hard of hearing workers less than those of deaf workers, and that hard of hearing workers may have been reluctant to ask for necessary accommodations.

Such reluctance perhaps reflects the apprehension about disclosing their hearing loss to employers or potential employers, out of the fear of being stigmatized or seeming less than 
competent on the job, that has been reported in studies of hard of hearing adults (Hallberg \& Carlsson, 1993; Hétu \& Getty, 1993; Laroche, Garcia, \& Barrette, 2000; Stika, 1997). Negative reactions of employers, supervisors, and co-workers constitute attitudinal barriers that people with hearing loss face in the workplace.

Anecdotal evidence from adults with hearing loss illustrates some of the attitudes that are encountered. For instance, a profoundly deaf psychologist has related his experiences in becoming qualified and working as a psychologist in the United Kingdom and the attitudes of other professionals toward him. He encountered reactions such as amazement among professionals working with the deaf, reflecting "their negative attitudes about what is possible for deaf people," and suspicions, "probably due to fear, that a deaf person had managed to work his way up to their level" (Jones, 1991, p.145). A young Australian with hearing loss has described surmounting the barriers involved in becoming a veterinary surgeon. He first had to convince a university admissions panel that he was capable of carrying out the tasks inherent in the job. He then designed and produced surgical masks with transparent plastic windows so that he could read the lips of his teachers during surgical training. Finally, he needed to overcome potential employers' reluctance to hire him because of concerns about his hearing loss (Kennedy, 2001). Similarly, Hauser, Maxwell-McCaw, Leigh, and Gutman (2000) have recounted incidents of negative attitudes and additional hurdles encountered by deaf and hard of hearing applicants for internships with American Psychological Association programs.

Thus, attitudinal barriers can interact with environmental barriers, affecting the career outcomes and advancement of workers with hearing loss. As well, attitudinal barriers that influence career outcomes can exist for deaf and hard of hearing students in the form of limited parent, teacher, or career counselor expectations. Studies in several countries of parents' and teachers' attitudes toward advising deaf youth to train for different occupations found that parents and teachers would give more encouraging advice to hearing people across a range of occupations than they would to equally qualified deaf people. The difficulties of interpersonal communication and safety issues were reasons given for the less-than-encouraging advice to deaf persons, with occupations dealing primarily with data and things rather than people deemed by advisors to be the most suitable for deaf people (DeCaro, Evans, \& Dowaliby, 1982; DeCaro, Mudgett-DeCaro, \& Dowaliby, 2001; Parasnis, DeCaro, \& Raman, 1996).

Although these studies pertain to youth who received schooling for the deaf and who were largely signing, the problem of limited expectations appears to affect hard of hearing youth also. 
In a Canadian study of hard of hearing youth, 20\% of the respondents reported that their parents' suggested career options were limited by concerns about their son's or daughter's hearing loss (Warick, 1994). A Swedish study investigating the school-to work transition of hard of hearing young adults 5 years after completing secondary school considered that parents were so supportive of whatever choices of upper-secondary education their children made that they had in the researchers' words - “abdicated” their responsibility in helping their children towards optimal outcomes, perhaps, the researchers speculated, because of lower expectations of their children's futures than those held by parents of normally hearing children (Danermark, Antonson, \& Lundstrom, 2001).

It is a matter for concern if parent, teacher, or counselor expectations exclude certain career options from exploration by students with hearing loss. It may seem sensible to encourage these young people to pursue careers which require a minimum of verbal, particularly vocal, interaction with people and a maximum of work with data or things. However, to limit career exploration in this way is detrimental in two ways. First, as we have already discussed in the present article, most occupations in the current employment environment require multiple skills, including a variety of communication skills. Second, applying such limits to career exploration ignores the individual's interests, intellectual capacity, values, and personality characteristics. Career theory and practice have long assumed that the fit of these factors to one's chosen occupation is vital to the individual's career success and satisfaction. If this is the case for the general population, it is hard to imagine that it should not be so for people with hearing loss.

\section{Career Maturity and Career Decision Making of Adolescents with Hearing Loss}

Career theorists and researchers emphasize the importance of the development of career maturity and career exploration skills and attitudes by adolescents if they are to successfully negotiate the school-to-work transition, particularly in light of the increasingly complex world of work and the changes in the labor market we have outlined in the present article (Blustein, 1997; Patton, 2000; Sweet, 1998). The concept of career maturity involves the readiness of an individual to make informed, age-appropriate career decisions (Super, 1957). Career maturity in adolescence has been empirically linked to later career success and satisfaction (Fouad, Smith, \& Enochs, 1997; Luzzo, Hitchings, Retish, \& Shoemaker, 1999; Ochs \& Roessler, 2001), and is particularly crucial for young people with disabilities if they are to overcome the disadvantages associated with their situation and succeed vocationally (Ochs \& Roessler). Careful career exploration and 
decision-making is likely to enhance the school-to-work transition and lead to better career outcomes for any young person. For deaf and hard of hearing adolescents in particular, such exploration and planning is essential if they are to minimize their potential communication and developmental disadvantages and place themselves in the best possible position to deal with the environmental and attitudinal barriers they are likely to encounter in the world of work. In addition, strong career planning skills are likely to reduce the alarmingly high (estimated at 75\%) rate of noncompletion of university degree programs among this population (Stinson \& Walter, 1997).

Although career maturity levels and career decision-making abilities are of crucial importance to young deaf and hard of hearing people, there is evidence that adolescents with hearing loss have a lower level of career maturity, involving reduced career awareness and lower career decision-making competencies, than normally hearing adolescents (Furlonger, 1998; J. Schroedel, 1991).

Significant hearing loss may impact on children's career development in several ways. First, the career-related information casually picked up by normally-hearing children through listening to others talking and to television and radio may be missed by deaf or hard of hearing children who have less auditory access to this kind of incidental learning (Furlonger, 1998). Second, some parents may be more protective of their deaf or hard of hearing child than they would be of a normally hearing child (Gregory, 1998; Luterman, 1999; Morgan-Redshaw, Wilgosh, \& Bibby, 1990; Warick, 1994), and consequently may limit their child's ageappropriate opportunities to explore the world and his or her own capabilities (King, 1992). Third, adolescents with hearing loss may have less experience of part-time employment during their secondary school years than their normally hearing peers. The types of after-school and holiday jobs obtained by many secondary school students, such as serving customers in shops or restaurants or cooking in busy fast-food outlets, because they involve receiving rapidly expressed oral requests and instructions, can pose particular difficulties for adolescents who are deaf or hard of hearing. It has been asserted that such work experience has a beneficial effect on adolescents' development, fostering responsibility, independence, changed self-concepts, and a greater awareness of interests (Mortimer, Shanahan, \& Ryu, 1994), as well as positively affecting certain work values, although not necessarily resulting in reduced career indecision (Skorikov \& Vondracek, 1997). For these reasons, it seems that deaf and hard of hearing adolescents may have less career maturity than their normally hearing peers. 
Unfortunately, there is a dearth of studies - and, consequently, a dearth of empirical evidence - on the career development of adolescents and young adults with hearing loss, as the few researchers who have investigated this area have pointed out (Furlonger, 1998; King, 1990a; J. Schroedel, 1992). The research that does exist is based largely on studies of students attending residential and day schools for the deaf, and thus is far from generalizable to the majority of students with hearing loss in countries whose current policies and trends have moved toward inclusion of these students in regular schools and classes.

In the United States, Schroedel $(1991,1992)$ investigated career decisions and career decision-making skills of students in grades 10-12 at residential and day schools for the deaf. Students were interviewed about the career development activities they had undertaken, and school counselors and teachers evaluated eight attributes of the career decision-making skills of each student. These evaluations indicated that approximately $60 \%$ of the students were considered to be aware of their vocational aptitudes and interests, while $61 \%$ were considered to be deficient in occupational knowledge. Students who had participated in career development activities were considered to be more career aware and motivated. However, these results derived from the opinions of the students' teachers and counselors. No established measures were administered to the students, and interviews of the students elicited only information about career awareness activities and other influences on their career aspirations, and not about their specific career aspirations or their career decision-making processes.

Another U.S. study (King, 1990a; , 1990b, , 1992) investigated the career maturity of adolescents with hearing impairments in order to determine the necessity of a separate theory of career development for people with hearing impairment. The study included 71 students in grades 10-12; 57 attended residential schools for the deaf and 14 were in regular schools, either in resource or mainstreamed programs. Hearing loss ranged from mild ( $9 \%$ of the sample) to profound (65\%). This group was compared to a group of 318 normally-hearing students attending public schools in the same area. Participants compiled a composite score on the Career Development Attitudes (CDA) scale by completing the Career Planning and Career Exploration subscales of the Career Development Inventory, or CDI (Thompson, Lindeman, Super, Jordaan, \& Myers, 1981). In addition, students’ family cohesion was rated using the 10-item cohesion scale of the Family Adaptability and Cohesion Evaluation Scales, or FACES III ( Olson, Portner, \& Lavee, 1985); school records supplied reading and mathematics achievement levels. Questionnaires completed by the parents provided background information and parental 
aspirations for their children's occupational attainment. Parents also completed a measure of cultural participation, indicating the number of different kinds of educational, reading, and recreational materials available in the home.

The results indicated similar mean CDA scores for the hearing-impaired and normally hearing groups. As King (1990a) pointed out, the aspect of career maturity explored in this study was the affective/attitudinal one of readiness to make career decisions, as measured by the CDA scale of the CDI, and not the cognitive dimensions of career maturity, or occupational aspirations or interests. The study did not include the cognitive component of the CDI in the form of the World of Work Information and Career Decision-Making subscales. Data compiled by means of these subscales would have also been valuable, particularly in light of the possibility that deaf and hard of hearing children miss out on incidental learning about the world of work and careers.

King designed a causal model of career maturity from the variables included in her study: gender, age, achievement level, parental socioeconomic status, parental aspirations, family cohesion, and cultural participation. She then constructed a second model with added variables specifically related to hearing impairment, such as degree of hearing loss, age at onset of hearing loss, parent-child communication, and degree of mainstreaming. Using path analyses, King tested the ability of each model to explain variance in the career maturity in the hearing-impaired and normally hearing groups of adolescents. She concluded that the second model, while more descriptive of the career development process of young people with hearing loss, was no more powerful in explaining variance in career maturity, and suggested that consequently there is no need for a separate theory of career development for people with hearing impairments (King, 1990a, 1990b, 1992).

In a New Zealand study (Furlonger, 1998) investigated the career development of 26 high school students, ages 13 to 18 years, with hearing loss, and a matched control group of normally hearing peers. The students with hearing-impairment all attended resource classes for the deaf in regular schools, spending at least some time in the schools’ regular classes. Students completed the Self-Directed Search (Keeling \& Tuck, 1982) and the Australasian revision of the CDI (Lokan, 1984). The students with hearing loss scored significantly lower than their normally hearing peers on three of the CDI's subscales - Career Planning, World of Work Information, and Career Decision Making - while showing no significant difference on the fourth scale, Career Exploration. Furlonger explained that the Career Planning subscale asks respondents to consider how much thought they have given to jobs and their prerequisites; the responses of the students 
with hearing loss indicated that they had discussed these matters with a relatively small circle of people. He stated that their responses on the World of Work Information and Career Decision Making subscales indicate that they "were less informed about how to relate to fellow workers, job hunting, types of occupations, and the tools of certain trades”, reflecting, perhaps, “a limited experiential base”, as suggested in the literature (p.274). He concluded from the study's findings that a developmental lag clearly existed in the career maturity of the study participants with hearing loss, and recommended improvements in the career education of deaf school students, including an emphasis on career awareness, career exploration, decision-making skills, and communication skills. He further suggested that such programs begin earlier for this population than is usual for normally hearing students.

Furlonger (1998) conducted his study relatively recently, and his sample was at least partially mainstreamed. The sample was also small - 26 students with hearing impairments and a control group of 26 hearing students. In the report of the study, the researcher does not clarify whether the students with hearing loss were deaf or hard of hearing, using the terms deaf and hearing impaired interchangeably; however, he does state that all instructions were delivered manually using New Zealand Sign Language and Signed English, and orally "when applicable” (p. 271), suggesting that most of the study participants used a sign language. This group consisted largely of students with profound hearing loss $(n=19)$, with 5 of the remainder having a severe loss, and only 2 a moderately severe loss. As well, all 26 were based in a resource class for students with hearing impairments. Thus, the sample was not representative of adolescents who may be defined as hard of hearing, that is, who are integrated into regular classes, and who are primarily oral-aural in their mode of communication.

These, then, constitute the few studies conducted in the last 15 years on the career development or career maturity of adolescents who are deaf or hard of hearing. Their conclusions are mixed - King (1990a, 1990b, 1992) found no significant difference between her hearing and hearing-impaired sample in CDA scores, whereas Furlonger (1998) found significantly lower scores for his hearing-impaired sample on three of the four subscales of the CDI. The participants in both Schroedel's (1991) and King's studies attended special schools for the deaf, either residential or day, while Furlonger's sample was based in resource classes for the deaf. However, no research has been reported into the career development of hard of hearing adolescents in fully integrated settings - a major group of students, given current policies and trends toward inclusive education. 


\section{Recommendations for Research and Practice}

The significant gap in the literature on the career development of youth with hearing loss strongly suggests not only the need for further research in general on this topic, but also investigations in several particular areas, for instance, perceived career barriers. Recent career development theorists have emphasized the significance of contextual and environmental factors and their role in constituting barriers and supports to individuals' career goals (e.g., Lent, Brown, \& Hackett, 1994; Swanson \& Woitke, 1997). It may be that hard of hearing adolescents perceive some of the effects of their hearing loss as career barriers and that they may consequently circumscribe their occupational goals. However, no studies have identified or examined specific career barriers that may be perceived by hard of hearing youth. Research into perceived barriers and potential supports would inform policies and practices that would aid the school-to-work transition of this population.

The research that has been conducted on the career development of young people with hearing loss has relied almost entirely on quantitative methods, even though qualitative methods may also be extremely beneficial to the investigation of this topic. Researchers and theorists have suggested that qualitative methods are needed to contribute insight and understanding into the career development experiences of adolescents (Blustein, 1997; Paa \& McWhirter, 2000) and may be particularly useful in "ferreting out" the phenomenological aspects and personal constructions of career barriers (Lent, Brown, \& Hackett, 2000, p. 48). Qualitative research can also be well suited to improving understanding of the interaction between career development and disability (Szymanski, Hershenson, Enright, \& Ettinger, 1996).

This overview of the literature suggests certain practices and interventions that could be implemented to the benefit of the career development of hard of hearing adolescents. In addition to the career education and guidance that is so important for all secondary school students, several, more specific interventions may benefit students with hearing loss:

- Facilitating informed choice by students by guiding them in the discovery of more detailed information about particular occupations, any potential difficulties their hearing loss may cause in particular occupational roles, and potential solutions to these 
difficulties. The use of deaf or hard of hearing role models from the workplace may further inform these decision-making processes.

- Educating students about the responsibilities of workplaces and institutions of higher education and training to provide necessary accommodations.

- Providing assertiveness training to enable hard of hearing students to confidently and appropriately explain their needs and make requests for accommodations, in job interview situations and in everyday interactions with workmates, colleagues, customers, clients, and others.

- Encouraging awareness in parents, teachers, and guidance counselors about the importance of conveying appropriately high expectations of career outcomes to students with hearing loss.

- Encouraging the growth of career maturity through assisting students to obtain part-time jobs or work experience.

\section{Conclusion}

This overview has pointed out the vulnerable position of young hard of hearing people in today's challenging labor market and the environmental and attitudinal barriers they face in the world of work. The lack of research studies into this population's career maturity and, in particular, into the way their perception of career barriers may influence their career decision-making strongly suggests the need for such research. Given the emphasis placed on career maturity and vocational knowledge as key outcomes of schooling, and the particular importance of these outcomes for students with hearing loss, it is important that this issue be investigated for this particular population. In addition to recommending practices and interventions, we suggest that further research will clarify the needs of hard of hearing adolescents and lead to the identification of additional practices that could be implemented to their benefit. 


\section{References}

Allen, T. E. (1986). Patterns of academic achievement among hearing-impaired students: 1974 and 1983. In A. N. Schildroth \& M. A. Karchmer (Eds.), Deaf children in America (pp. 161-206). San Diego, CA: College-Hill Press.

Allen, T. E. (1994). School and demographic predictors of transition success: A longitudinal assessment. In T. E. Allen, Lam, K. H., Rawlings, B. W., Rose, D. E., \& Schildroth, A. N. (Ed.), Young deaf adults and the transition from high school to postsecondary careers (pp. 61-70). Washington, DC: Gallaudet University.

Australian Bureau of Statistics. (2002a). Education and training indicators. Catalogue 4221.0. Canberra: ABS.

Australian Bureau of Statistics. (2002b). Year book Australia: Labour - persons unemployed. Catalogue 1301.0. Canberra: ABS.

Bat-Chava, Y., Rosen, R. B., Sausa, A., Meza, C., Schockett, S., \& Deignan, E. (1999). An evaluation of a college preparatory and readiness progam for deaf students. Journal of Rehabilitation, 65(2), 51-59.

Blustein, D. L. (1997). A context-rich perspective of career exploration across the life-roles. The Career Development Quarterly, 45, 260-274.

Bonds, B. G. (2003). School-to-work experiences: curriculum as bridge. American Annals of the Deaf, 148(1), 38-48.

Bullis, M., Bull, B., Freeburg, J., \& Sendelbaugh, J. (1990). Education and community integration experiences of deaf adolescents and young adults. In R. Gaylord-Ross (Ed.), Issues and research in special education (Vol. 1, pp. 297-354). New York: Teachers College Press.

Bullis, M., Bull, B., Johnson, B., \& Peters, D. (1995). The school-to-community transition experiences of hearing young adults and young adults who are deaf. Journal of Special Education, 28(4), 405-423.

Bureau of Labor Statistics. (2003). Labor force statistics from the current population survey. Series ID LNS14000012: U.S. Department of Labor.

Conrad, R. (1979). The deaf school child. London: Harper and Row.

Danermark, B., Antonson, S., \& Lundstrom, I. (2001). Social inclusion and career development transition from upper secondary school to work or post-secondary education among hard of hearing students. Scandinavian Audiology, 30, 120-128.

DeCaro, J. J., Evans, L., \& Dowaliby, F. J. (1982). Advising deaf youth to train for various occupations: Attitudes of significant others. British Journal of Educational Psychology, 52, 220-227.

DeCaro, J. J., Mudgett-DeCaro, P. A., \& Dowaliby, F. J. (2001). Attitudes toward occupations for deaf youth in Sweden. American Annals of the Deaf, 146(1), 51.

El-Khiami, A. (1993). Employment transitions and establishing careers by postsecondary alumni with hearing loss. The Volta Review, 95, 357-366.

Fouad, N. A., Smith, P. L., \& Enochs, L. (1997). Reliability and validity evidence for the Middle School Self-Efficacy Scale. Measurement and Evaluation in Counseling and Development, 30, 17-31.

Furlong, A., \& Cartmel, F. (1997). Young people and social change: Individualization and risk in late modernity. Buckingham: Open University Press. 
Furlonger, B. (1998). An investigation of the career development of high school adolescents with hearing impairments in New Zealand. American Annals of the Deaf, 143(3), 268-276.

Geers, A., \& Moog, J. (1989). Factors predictive of the development of literacy in profoundly deaf hearing-impaired adolescents. The Volta Review, 91(1), 69-86.

Geyer, P. D., \& Schroedel, J. G. (1999). Conditions influencing the availability of accommodations for workers who are deaf or hard-of-hearing. Journal of Rehabilitation, 65(2), 42-50.

Gregory, S. (1998). Deaf young people: Aspects of family and social life. In M. Marschark (Ed.), Psychological perspectives on deafness (Vol. 2, pp. 153-170). Mahwah, NJ: Lawrence Erlbaum Associates.

Hall, D. T., \& Mirvis, P. H. (1996). The new protean career: Psychological success and the path with a heart. In Douglas T. Hall \& Associates (Eds.), The career is dead - long live the career: A relational approach to careers. San Francisco: Jossey-Bass.

Hallberg, L. R.-M., \& Carlsson, S. G. (1993). A qualitative study of situations turning a hearing disability into a handicap. Disability, Handicap and Society, 8(1), 71-85.

Harlan, S. L., \& Robert, P. M. (1998). The social construction of disability in organizations: Why employers resist reasonable accommodation. Work and Occupations, 25(4), 397435.

Hauser, P. C., Maxwell-McCaw, D., Leigh, I., \& Gutman, V. (2000). Internship accessibility issues for deaf and hard-of-hearing applicants: No cause for complacency. Professional Psychology: Research and Practice, 31(5), 569-574.

Hétu, R., \& Getty, L. (1993). Overcoming difficulties experienced in the work place by employees with occupational hearing loss. The Volta Review, 95, 391-402.

Hyde, M. (1988). Post-secondary education needs of young people with hearing impairment in Queensland. Australian Disability Review, 1(1), 21-25.

Hyde, M., \& Power, D. (1992). The use of Australian Sign Language by deaf people. Australian Disability Review, 3, 30-41.

Israelite, N., Ower, J., \& Goldstein, G. (2002). Hard-of-hearing adolescents and identity construction: Influences of school experiences, peers, and teachers. Journal of Deaf Studies and Deaf Education, 7, 134-148.

Jones, C. (1991). A deaf psychologist. In G. Taylor \& J. Bishop (Eds.), Being deaf: The experience of deafness (pp. 143-155). London: Pinter.

Keeling, B., \& Tuck, B. F. (1982). Counselor's manual for the Self-Directed Search. Wellington, New Zealand: New Zealand Council for Educational Research.

Kennedy, A. (2001). It's not just about volume. Committee for Hearing Impaired Children Newsletter, 46, 3-4.

King, S. (1990a). Background and family variables in a causal model of career maturity: Comparing hearing and hearing-impaired adolescents. The Career Development Quarterly, 38, 240-260.

King, S. (1990b). Comparing two causal models of career maturity for hearing-impaired adolescents. American Annals of the Deaf, 135(1), 43-49.

King, S. (1992). The career development of young people with hearing impairments. In T. N. Kluwin, D. F. Moores \& M. G. Gaustad (Eds.), Toward effective public school programs for deaf students (pp. 217-237). New York: Teachers College Press.

Lam, K. H. (1994). Non-college bound deaf youth. In T. E. Allen, K. H. Lam, B. W. Rawlings, D. E. Rose \& A. N. Schildroth (Eds.), Young deaf adults and the transition from high school to postsecondary careers (pp. 7-16). Washington DC: Gallaudet University. 
Lamb, S., \& McKenzie, P. (2001). Patterns of success and failure in the transition from school to work in Australia. LSAY Research Report 18, Melbourne: ACER.

Laroche, C., Garcia, L. J., \& Barrette, J. (2000). Perceptions by persons with hearing impairment, audiologists, and employers of the obstacles to work integration. Journal of the Academy of Rehabilitative Audiology, 33, 63-90.

Laszlo, C. (1994). Is there a hard-of-hearing identity? Journal of Speech Language Pathology and Audiology, 18(4), 248-252.

Lent, R. W., Brown, S. D., \& Hackett, G. (1994). Toward a unifying social cognitive theory of career and academic interest. choice, and performance. Journal of Vocational Behavior, 45, 79-122.

Lent, R. W., Brown, S. D., \& Hackett, G. (2000). Contextual supports and barriers to career choice: A social cognitive analysis. Journal of Counseling Psychology, 47(1), 36-49.

Lewis, S. (1996). The reading achievements of a group of severely and profoundly hearingimpaired school leavers educated within a natural aural approach. Journal of British Association of Teachers of the Deaf, 20(1), 1-7.

Lokan, J. (1984). Manual of the Career Development Inventory - Australian Edition. Melbourne: Australian Council for Educational Research.

Long, M., Carpenter, P., \& Hayden, M. (1999). Participation in education and training 19801994. LSAY Research Report, Melbourne: ACER.

Luckner, J. L., \& Muir, S. (2001). Successful students who are deaf in general education settings. American Annals of the Deaf, 146(5), 435-446.

Luterman, D. M. (1999). The young deaf child. Baltimore: York Press.

Luzzo, D. A., Hitchings, W. E., Retish, P., \& Shoemaker, A. (1999). Evaluating differences in college students' career decision making on the basis of disability status. The Career Development Quarterly, 48, 142-156.

Lynas, W., Lewis, S., \& Hopwood, V. (1997). Supporting the education of deaf children in mainstream schools. Journal of the British Association of Teachers of the Deaf, 21(2), 4145.

MacLeod-Gallinger, J. E. (1992). The career status of deaf women: A comparative look. American Annals of the Deaf, 137(4), 315-325.

McCowan, C., \& McKenzie, M. (1997). The guide to career education: For careers personnel working in Australian schools and colleges. North Sydney, NSW: New Hobsons Press.

McLean, P., Osborne, V., McAuliffe, J., Housden, T., \& Revens, E. (1999). Optimising the learning experience for Deaf and hearing impaired students: Victorian Co-operative Projects Higher Education Students with a Disability Committee.

Mirvis, P. H., \& Hall, D. T. (1996). New organizational forms and the new career. In Douglas T. Hall \& Associates (Eds.), The career is dead - long live the career. San Francisco: JosseyBass.

Moores, D. F. (2001). Educating the deaf: Psychology, principles and practices (5th ed.). Boston: Houghton Mifflin.

Morgan-Redshaw, M., Wilgosh, L., \& Bibby, M. A. (1990). The parental experiences of mothers of adolescents with hearing impairments. American Annals of the Deaf, 135(4), 293-298.

Mortimer, J. T., Shanahan, M., \& Ryu, S. (1994). The effects of adolescent employment on school-related orientation and behavior. In R. K. Silbereisen \& E. Todt (Eds.), Adolescence in context: The interplay of family, school, peers, and work in adjustment (pp. 304-326). New York: Springer-Verlag. 
Murphy, V., \& Noad, P. (1995). The future labour market: Implications for people with disabilities. Paper presented at the Third National Rehabilitation Conference, "Rehabilitation: Investing in the Future", Brisbane.

Ochs, L. A., \& Roessler, R. T. (2001). Students with disabilities: How ready are they for the 21st century? Rehabilitation Counseling Bulletin, 44(3), 170-176.

Olson, D. H., Portner, J., \& Lavee, Y. (1985). FACES III: Family Adaptability and Cohesion Evaluation Scales. St. Paul, MN: University of Minnesota.

Paa, H. K., \& McWhirter, E. H. (2000). Perceived influences on high school students' current career expectations. The Career Development Quarterly, 49, 29-44.

Parasnis, I., DeCaro, J. J., \& Raman, M. L. (1996). Attitudes of teachers and parents in India toward career choice for deaf and hearing people. American Annals of the Deaf, 141(4), 303-308.

Patton, W. (2000). The nexus between vocational education and career education in schools. Australian Journal of Career Development, 9(3), 34-39.

Power, D. (1998). Deaf and hard of hearing students in Australia. In A. Ashman \& J. Elkins (Eds.), Educating children with special needs (pp. 346-381). Sydney: Prentice Hall.

Power, D., \& Hyde, M. (2002). The characteristics and extent of participation of deaf and hard of hearing students in regular classes in Australian schools. Journal of Deaf Studies and Deaf Education, 7(4), 302-311.

Rawlings, B. W. (1994). Postsecondary education: Its impact and outcomes. In T. E. Allen, K. H. Lam, B. W. Rawlings, D. E. Rose \& A. N. Schildroth (Eds.), Young deaf adults and the transition from high school to postsecondary careers (pp. 17-31). Washington DC: Gallaudet University.

Scherich, D. (1996). Job accommodations in the workplace for persons who are deaf or hard of hearing: Current practices and recommendations. Journal of Rehabilitation, 62(2), 27.

Scherich, D., \& Mowry, R. (1997). Accommodations in the workplace for people who are hard of hearing: Perception of employees. Journal of the American Deafness and Rehabilitation Association, 31(1), 31-43.

Schildroth, A., Rawlings, B., \& Allen, T. (1991). Deaf students in transition: Education and employment issues for deaf adolescents. The Volta Review, 93(5), 41-53.

Schroedel, J. (1991). Improving the career decisions of deaf seniors in residential and day high schools. American Annals of the Deaf, 136(4), 330-338.

Schroedel, J. (1992). Helping adolescents and young adults who are deaf make career decisions. The Volta Review, January, 37-46.

Schroedel, J. G., \& Geyer, P. D. (2000). Long-term career attainments of deaf and hard of hearing college graduates: Results from a 15-year follow-up survey. American Annals of the Deaf, 145(4), 303-314.

Skorikov, V. B., \& Vondracek, F. W. (1997). Longitudinal relationships between part-time work and career development in adolescents. The Career Development Quarterly, 45, 221-235.

Stika, C. J. (1997). Living with hearing loss - focus group results Part II: Career development and work experiences. Hearing Loss, 18(6), 29-32.

Stinson, M., \& Walter, G. (1997). Improving retention rate for deaf and hard of hearing students: What the research tells us. Journal of the American Deafness and Rehabilitation Association, 30(4), 14-23.

Super, D. E. (1957). The psychology of careers. New York: Harper \& Row.

Swanson, J. L., \& Woitke, M. B. (1997). Theory into practice in career assessment for women: Assessment and interventions regarding perceived career barriers. Journal of Career Assessment, 5(4), 443-462. 
Sweet, R. (1998). Youth: The rhetoric and the reality of the 1990s. In Dusseldorp Skills Forum (Ed.), Australia's youth: Reality and risk (pp. 5-22). Sydney: Dusseldorp Skills Forum.

Szymanski, E. M., \& Hershenson, D. B. (1998). Career development for people with disabilities: An ecological model. In R. M. Parker \& E. M. Szymanski (Eds.), Rehabilitation counseling: Basics and beyong (3rd ed., pp. 327-378). Austin, Texas: Pro-ed.

Szymanski, E. M., Hershenson, D. B., Enright, M. S., \& Ettinger, J. M. (1996). Career development theories, constructs, and research: Implications for people with disabilities. In E. M. Szymanski \& R. M. Parker (Eds.), Work and disability: Issues and strategies in career development and job placement. Austin, Texas: Pro-ed.

Thompson, A. S., Lindeman, R. H., Super, D. E., Jordaan, J. P., \& Myers, R. A. (1981). The Career Development Inventory. Palo Alto, CA: Consulting Psychologists.

Toscano, R., McKee, B., \& Lepoutre, D. (2002). Success with academic English: Reflections of deaf college students. American Annals of the Deaf, 147(1), 5-23.

Vondracek, F. W., \& Porfeli, E. J. (2003). The world of work and careers. In G. R. Adams \& M. D. Berzonsky (Eds.), Blackwell handbook of adolescence (pp. 109-128). Malden, MA: Blackwell.

Warick, R. (1994). A profile of Canadian hard-of-hearing youth. Journal of Speech Language Pathology and Audiology, 18(4), 253-259.

Watts, A. G. (1997). Careerquake. Australian Journal of Career Development, 6(2), 36-40.

Welsh, W. A. (1993). Factors influencing career mobility of deaf adults. The Volta Review, 95, 329-339.

Winn, S. (1997). Being female and deaf - a double disability? Paper presented the Twentieth conference of the Australian Association of Teachers of the Deaf, Adelaide.

World Health Organization. (1980). International classification of impairments, disabilities and handicaps: A manual of classification relating to the consequences of disease. Geneva: World Health Organization. 